\title{
Quality of life of people with diabetic foot
}

\author{
Qualidade de vida de pessoas com pé diabético
}

Pedro Martins Lima Neto ${ }^{1}$, Paulo Henrique Silva de Lima ${ }^{1}$, Francisco Dimitre Rodrigo Pereira Santos ${ }^{1}$, Layane Mota de Souza de Jesus ${ }^{1}$, Raina Jansen Cutrim Propp Lima ${ }^{2}$, Leonardo Hunaldo dos Santos ${ }^{1}$

Objective: evaluate the quality of life of people with diabetic foot and its association with age and gender. Methods: cross-sectional study conducted with people with diabetic foot seen in the vascular clinic of a Municipal Hospital. Sociodemographic, clinical, lifestyle and evaluation of quality of life SF-36 questionnaires were used. Results: sample was consisted of 48 people. The majority was elderly (58.4\%), female (56.3\%), nonsmoker (93.7\%), non-alcoholic (83.4\%), with recurrence of ulcers (50.0\%), with present secretion (54.2\%) and absent fetid odor (81.3\%). Regarding quality of life, the best result was in the domain vitality and the worse, in the domain physical aspects. All domains, except the vitality, had a score below 50 in the measurement of quality of life. There was no significant difference in the comparison of quality of life between age groups and gender. Conclusion: participants presented domains of quality of life that tend to a poorer health status.

Descriptors: Quality of Life; Diabetic Foot; Foot Ulcer.

Objetivo: avaliar a qualidade de vida de pessoas com pé diabético e sua associação com idade e sexo. Métodos: estudo transversal realizado com pessoas com pé diabético atendidas na clínica vascular de um hospital municipal. Foram utilizados questionários sociodemográfico, clínico, de estilo de vida e de avaliação de qualidade de vida SF-36. Resultados: amostra de 48 pessoas, maioria idosa (58,4\%), sexo feminino (56,3\%), não tabagista (93,7\%), não etilista (83,4\%), com reincidência das úlceras $(50,0 \%)$, secreção presente $(54,2 \%)$ e odor fétido ausente $(81,3 \%)$. Quanto à qualidade de vida, o melhor resultado foi no domínio vitalidade e pior no domínio aspectos físicos. Todos os domínios, exceto a vitalidade, apresentaram escore abaixo de 50 na mensuração da qualidade de vida. Não houve diferença significante na comparação da qualidade de vida entre faixas etárias e sexo. Conclusão: os participantes apresentaram domínios de qualidade de vida que tendem a um pior estado de saúde.

Descritores: Qualidade de Vida; Pé Diabético; Úlcera do Pé.

\footnotetext{
${ }^{1}$ Universidade Federal do Maranhão. Imperatriz, MA, Brazil.

${ }^{2}$ Instituto Federal de Educação, Ciência e Tecnologia do Maranhão. Açailândia, MA, Brazil. 65.900-000 - Imperatriz, MA, Brazil. E-mail: pedro.martins@ufma.br
} 


\section{Introduction}

Currently, there has been an epidemic of Diabetes Mellitus, since estimates indicated that there were 30 million adult diabetics in the world in 1985, a number that reached 135 million in 1995, reaching 415 million in 2015, with estimates to reach 642 million in 2040. in Brazil, there were 14.3 million people with diabetes in 2015, which represented $9.4 \%$ of the national population that year ${ }^{(1-2)}$.

Diabetes Mellitus can cause complications that can be acute or chronic. Acute complications are mainly diabetic ketoacidosis and hyperglycemic hyperosmolar state. The chronic complications of diabetes mellitus can be microvascular, macrovascular and neuropathic; its pathogenesis are probably involved in interactions between genetic and metabolic factors ${ }^{(3)}$.

This disease affects the feet in a critical and intense manner, causing changes in all its components, such as arterial, venous and lymphatic vessels, muscles, bones, joints, skin and nerves ${ }^{(1)}$.

Diabetic foot is a term used to designate the various changes accompanied by infection, ulceration and/or destruction of deep tissues associated with neurological abnormalities and various degrees of peripheral vascular disease in the lower limbs, which may inevitably develop into amputations $\mathbf{s}^{(4-5)}$.

The consequences of diabetic foot ulcers are not limited only to the lower limb but also to the decrease of quality of life of people and their caregivers due to disabilities, premature mortality that may result major cases of repeated hospitalizations, prolonged rehabilitation and need of social support, leading to increasingly higher $\operatorname{costs}^{(6)}$.

These lesions bring suffering to patients by modifying their lifestyle to the extent that they need help to perform activities of daily life and may have their autonomy impaired, becoming dependent on family and friends. There must be a reorientation in health care provided to people with diabetic foot ulcers, as the health services are responsible for identifying the presence of changes in the quality of life of these individuals ${ }^{(7)}$.

This research aimed to evaluate the quality of life of people with diabetic foot and its association with age and gender.

\section{Methods}

This is a cross-sectional study held from a convenience sample of 48 consecutive patients followed from August to December 2014, according to a pre-defined evaluation protocol for diabetic patients of the vascular outpatient clinic of the Municipal Hospital of Imperatriz, in the city of Imperatriz, Maranhão, Brazil, which provides public health care for people with Diabetes Mellitus and who have the diabetic foot.

The vascular outpatient clinic performs an average of 10 daily attendances, including consultations and dressings. The sector consists of a consultation room, a dressing room and a reception. The health team is composed of five doctors (two vascular surgeons, an endocrinologist, a cardiologist and a general practitioner) and three nursing technicians.

To compose the sample, interviewers had visited the vascular clinic weekly, from Monday to Friday, in the morning and afternoon shifts. Inclusion criteria were: having diagnosis of type 1 or type 2 diabetes mellitus, presenting diabetic foot, being eighteen years old or older, of both sexes, and receiving care in the vascular outpatient clinic of the aforementioned hospital. All people who met these criteria and agreed to participate were interviewed and evaluated, with no losses during the study.

Authors used two questionnaires, one addressing the sociodemographic, clinical and lifestyle variables of people with diabetic foot and another to 
evaluate the quality of life. The variables of the first questionnaire were selected and discussed among professionals with expertise in the area and then subjected to pre-test to correct any formulation errors with a representative sample of people with diabetic foot. There was no need to change this instrument after the completion of the pre-test.

Researchers read the questionnaire to the respondents to ensure the uniformity of the questions. It included the variables age ( $<60$ and $\geq 60$ years old), gender (male and female), marital status (married, single, divorced and widowed), smoking (individual who stated having ever smoked more than 100 cigarettes, or five packets of cigarettes during their lifetime and is still smoking), alcohol consumption (individual who have consumed at least one alcoholic drink in the last 30 days and is still drinking), ulcer recurrence (return of ulcerations after treatment: no or yes), ulcer with presence of secretion (no or yes) and ulcer with foul-smelling (no or yes).

The quality of life was assessed using the generic questionnaire Medical Outcomes Study 36Item Short-Form Health Survey (SF-36). This is one of the most frequently used instruments in health area worldwide, valued at more than 200 diseases and translated in 40 countries. This instrument has been translated into Portuguese and validated, with significant and highly satisfactory reproducibility ${ }^{(8)}$.

The SF-36 consists of thirty-six items grouped into eight domains: Functional Capacity, Physical Aspects, Emotional Aspects, Pain, General Health, Vitality, Social Aspects and Mental Health, which are analyzed separately from final scores ranging from zero to one hundred, where zero corresponds to the worst health status and one hundred corresponds to better health status. It also has a question that does not fit in any of the domains and aims to compare the current health conditions with the health conditions of a year ago.

The quality of life of participants was analyzed using the eight domains listed in the SF-36. The mean values obtained in these domains were compared in two forms of grouping: (1) elderly ( $\geq 60$ years old) (1) and non-elderly ( $<60$ years old); (2) male and female.

Because of the discrete quantitative variables, treatments were evaluated regarding the variables mentioned using the nonparametric U WilcoxonMann-Whitney test (two independent samples) at 5\% significance level, where there are no assumptions about the distribution of $\operatorname{data}^{(9)}$. All data were tabulated in Microsoft Excel 2013 spreadsheet and the tests were performed using the Statistical Analysis System program ${ }^{(9-10)}$.

To find out whether studies on quality of life have been developed with people with diabetic foot in the city of Imperatriz, Maranhão state, researchers carried out a literature survey in the online databases available, Scientific Electronic Library Online and Latin American and Caribbean Health Sciences, but no research that addressed this issue regionally was found.

The present study complied with the formal requirements contained in the national and international standards of regulatory research involving human subjects.

\section{Results}

Of the 48 respondents, $58.4 \%$ were 60 years old or older, $56.3 \%$ were female, $54.2 \%$ were married, 93.7\% were smokers, $83.4 \%$ were not considered alcoholics, $50.0 \%$ had recurrence of ulcers, $54.2 \%$ had secretion and $81.3 \%$ did not have ulcers with foul odor (Table 1).

Regarding quality of life, the sample showed better results in the domain Vitality and worst results in the domain Physical Aspects. Moreover, all domains, including the overall average of the sample showed results below the score 50 in the measurement of quality of life, except Vitality, which had an average of 56.21 (Table 2). 
Table 1 - Sociodemographic and clinical profile of people with diabetic foot

\begin{tabular}{|c|c|c|}
\hline Variables & n(\%) & (CI 95\%) \\
\hline \multicolumn{3}{|l|}{ Age } \\
\hline$<60$ & $20(41.6)$ & $27.7-55.5$ \\
\hline$\geq 60$ & $28(58.4)$ & $44.5-72.3$ \\
\hline \multicolumn{3}{|l|}{ Gender } \\
\hline Male & $21(43.7)$ & $29.7-57.7$ \\
\hline Female & $27(56.3)$ & $42.3-70.3$ \\
\hline \multicolumn{3}{|c|}{ Marital status } \\
\hline Married & $26(54.2)$ & $40.1-68.3$ \\
\hline Single & $13(27.1)$ & $14.5-39.7$ \\
\hline Divorced & $4(8.3)$ & $0.5-16.1$ \\
\hline Widowed & $5(10.4)$ & $1.8-19.0$ \\
\hline \multicolumn{3}{|l|}{ Smoker } \\
\hline No & 45 (93.7) & $86.8-100.0$ \\
\hline Yes & $3(6.3)$ & $0.0-13.2$ \\
\hline \multicolumn{3}{|c|}{ Alcohol comsumption } \\
\hline No & $40(83.4)$ & $72.9-93.9$ \\
\hline Yes & 8 (16.6) & $6.1-27.1$ \\
\hline \multicolumn{3}{|c|}{ Ulcer recurrence } \\
\hline No & $24(50.0)$ & $35.9-64.1$ \\
\hline Yes & $24(50.0)$ & $35.9-64.1$ \\
\hline \multicolumn{3}{|c|}{ Ulcer with secretion } \\
\hline No & $22(45.8)$ & $31.7-59.9$ \\
\hline Yes & $26(54.2)$ & $40.1-68.3$ \\
\hline \multicolumn{3}{|c|}{ Ulcer with foul odor } \\
\hline No & $39(81.3)$ & $70.3-92.3$ \\
\hline Yes & $9(18.7)$ & $7.7-29.7$ \\
\hline
\end{tabular}

Table 2 - Descriptive statistics for the domains relating to the quality of life in people with diabetic foot

\begin{tabular}{lcc}
\hline Quality of life & Average & $\begin{array}{c}\text { Standard } \\
\text { deviation }\end{array}$ \\
\hline Emotional aspects & 38.33 & 23.60 \\
Physical aspects & 15.10 & 29.96 \\
Social aspects & 43.77 & 31.20 \\
Functional capacity & 42.77 & 16.87 \\
Pain & 48.23 & 25.44 \\
General status & 48.63 & 35.16 \\
Mental health & 45.85 & 45.96 \\
Vitality & 56.21 & 25.73 \\
Overall average & 42.36 & - \\
\hline
\end{tabular}

There was no significant statistical difference in quality of life between different age groups and gender (Tables 3 and 4).
Table 3 - Mean values (standard deviation) for the domains relating to the quality of life in people with diabetic foot according to age

\begin{tabular}{lcc}
\hline \multirow{2}{*}{ Quality of life (Domains) } & \multicolumn{2}{c}{ Age (years) } \\
\cline { 2 - 3 } Emotional aspects & $\mathbf{< 6 0}(\mathbf{n = 2 0})$ & $\mathbf{2 6 0}(\mathbf{n = 2 8})$ \\
Physical aspects & $20.35(47.29) \mathrm{a}$ & $47.64(45.78) \mathrm{a}$ \\
Social aspects & $40.20(32.75) \mathrm{a}$ & $54.64(36.15) \mathrm{a}$ \\
Functional capacity & $40.75(23.52) \mathrm{a}$ & $36.61(23.92) \mathrm{a}$ \\
Pain & $40.20(34.20) \mathrm{a}$ & $46.32(29.24) \mathrm{a}$ \\
General status & $37.80(15.53) \mathrm{a}$ & $46.31(17.15) \mathrm{a}$ \\
Mental health & $52.00(23.79) \mathrm{a}$ & $59.21(27.04) \mathrm{a}$ \\
Vitality & $46.25(22.35) \mathrm{a}$ & $49.64(27.75) \mathrm{a}$ \\
\hline
\end{tabular}

aean values with different letters in the same row are statistically different by the U Wilcoxon-Mann-Whitney test at 5\% significance

Table 4 - Mean values (standard deviation) for the domains relating to the quality of life in people with diabetic foot according to gender

\begin{tabular}{lcc}
\hline \multirow{2}{*}{ Quality of life (Domains) } & \multicolumn{2}{c}{ Gender } \\
\cline { 2 - 3 } & Male (n=21) & Female (n=27) \\
\hline Emotional aspects & $51.89(47.53) \mathrm{a}$ & $38.10(42.58) \mathrm{a}$ \\
Physical aspects & $16.67(31.95) \mathrm{a}$ & $13.10(26.94) \mathrm{a}$ \\
Social aspects & $50.15(37.22) \mathrm{a}$ & $46.67(32.06) \mathrm{a}$ \\
Functional capacity & $42.96(26.14) \mathrm{a}$ & $32.38(18.82) \mathrm{a}$ \\
Pain & $47.89(34.20) \mathrm{a}$ & $38.48(25.77) \mathrm{a}$ \\
General status & $43.30(17.42) \mathrm{a}$ & $42.10(16.09) \mathrm{a}$ \\
Mental health & $61.11(28.35) \mathrm{a}$ & $49.90(20.65) \mathrm{a}$ \\
Vitality & $47.78(27.57) \mathrm{a}$ & $48.81(22.30) \mathrm{a}$ \\
\hline a Mean values with different letters in the same row are statistically different \\
by the U Wilcoxon-Mann-Whitney test at 5\% significance
\end{tabular}

\section{Discussion}

The characterization of the sample showed that most people with diabetic foot were seniors. A survey conducted in the city of Planura, Minas Gerais, Brazil, also found that the elderly were the majority among people with diabetic foot treated in health institutions $^{(11)}$.

The sample was also characterized by gender, 
in which prevailed the female, different from that found at a clinic for diabetes in the city of Ribeirão Preto, São Paulo, Brazil, which showed slightly higher rate for males among diabetics with foot ulcers ${ }^{(12)}$.

The present research identified that most people with diabetic foot were married, which was similar to another study, as when the profile of individuals with diabetic foot treated at the Retina and Vitreous Clinic of the State Public Servant Hospital of São Paulo was traced ${ }^{(13)}$.

Smokers were minority in this research, differing from the results of research conducted in a hospital with people with Diabetes Mellitus and ulcerated foot, which showed a higher number of smokers than nonsmokers among diabetics with foot ulcers. Alcoholics were also minority in the research sample of people with diabetic foot in Imperatriz, Maranhão, Brazil ${ }^{(14)}$.

It should be noted that, to prevent amputations from ulcers in the lower extremities, it is important a complete cessation of smoking and alcohol consumption by diabetics ${ }^{(5)}$.

Regarding the diabetic foot ulcer, three aspects were highlighted: whether the ulcer was recurrent, whether it had secretion and whether it had fetid odor. The ulcer had healed in half the subjects and had returned to appear. Most people with diabetic foot had some type of secretion. The fetid odor of the ulcer was found in few individuals in the sample.

By relating the results found with other research that aimed to assess the degree of depression and depressive symptoms of people with diabetic foot, the presence of secretion was also a feature observed in most individuals. However, in that same research, the number of individuals who had recurrence of ulcers was higher than those in whom there was no recurrence, and the presence of fetid odor also occurred in most individuals, diverging from the results obtained in this study ${ }^{(15)}$.

Among the SF-36 domains found in individuals with diabetic foot, the domain Vitality had the highest score in the quality of life instrument, which was similar to data from two wound care centers in São Paulo, Brazil, in which the domain Vitality had the best result in the quality of life in a group of diabetics with foot ulcers. However, the value of Vitality in quality of life had a much higher score in the survey conducted in Imperatriz, Maranhão, Brazil, showing that the level of energy and willingness to perform daily tasks, as measured through questions as the level of fatigue and exhaustion, proved to be better than in the sample of the other study ${ }^{(7)}$.

On the other hand, the domain Physical Aspects got the worst score among the SF-36 domains. This diverged from another publication developed in São Paulo, Brazil, when it was found the Functional Capacity was the worst evaluated domain in the quality of life of people with diabetic foot, but agreed to the results obtained in Pouso Alegre, Minas Gerais, Brazil, that found the Physical Aspects as the worst evaluated domain ${ }^{\text {(7-16). }}$

Another domain that received a low score was Emotional Aspects, in agreement with what was found in a city in Minas Gerais, Brazil, that presented this domain with low scores in the SF-36 among people with diabetic foot ${ }^{(16)}$.

An accurate analysis should be considered when the Physical Aspects are limited, as demonstrated in research with people with diabetic foot in Imperatriz, Maranhão, Brazil, for the physical disabilities caused by diabetic foot cause a major socioeconomic impact due to loss of jobs and productivity ${ }^{(17)}$.

The Emotional Aspects should also be studied in people with ulcers, as fear, grief and helplessness are common in these people because society values independence, and relying on others can lead to frustration $^{(15)}$.

The SF-36 domains evaluated in the total sample of people with diabetic foot presented, in all domains assessed, values below score 50, except the Vitality, that showed a value above the score 50 . As the SF-36 evaluates the quality of life according to the score obtained in the eight domains, it can be said that individuals with diabetic foot presented in Functional 
Capacity, Physical Aspects, Emotional Aspects, General Health, Mental Health, Pain and Social Aspects worse values related to quality of life since they are below the average of extreme values, indicating worse health status related to these areas.

Diabetes mellitus in the elderly is an important public health problem because this population has a higher propensity to develop heart problems, such as ischemic heart diseases, and amputations due to foot problems $^{(18)}$.

Because of these characteristics addressed in these studies, authors conducted the analysis of the quality of life of people with diabetic foot aged 60 years or older compared to that of the group with less than 60 years old. However, there was no significant statistical difference between the groups, because the p-value was greater than 0.05 in all domains assessed.

Regarding gender, a cross-sectional survey conducted in the Emergency Room of the Fortaleza General Hospital found a greater number of attendances to women than to men with diabetic foot, and the study carried out in the Cardiology Diagnostic Service of Pará State University also verified a higher number of women with diabetic foot. These authors have suggested that women need emergency care or more hospitalization when it comes to diabetic foot, which may indicate that there are differences in the quality of life of individuals with Diabetes Mellitus and foot ulcers related to gender ${ }^{(19-20)}$.

The comparison of the domains of quality of life between male and female got no statistically significant difference, so it was found that it also did not differ in relation to gender.

A limitation of this study was the non-use of a specific tool for assessing the quality of life of people with diabetes mellitus and diabetic foot, given that the generic instrument is not directed to the specific characteristics of this disease. The small sample size also implies limitation for statistical analysis and the support of findings.

\section{Conclusion}

The quality of life of people with diabetic foot the city of Imperatriz, Maranhão, Brazil, tended to a worse state of health in all evaluated domains, except in the domain Vitality. The sample analysis showed that there were no statistically significant differences in quality of life according to characteristics such as age and gender.

Because it is an unprecedented research with people with diabetic foot in the region of Imperatriz, Maranhão, Brazil, this study revealed the existence of important problems that have not been addressed in scientific studies and thus should serve for future research are developed, by planning specific actions focused on the health of people with diabetic foot, aiming to improve their quality of life.

\section{Collaborations}

Lima Neto PM and Lima PHS contributed to the collection, organization, analysis and interpretation of data, article writing and final version to be published. Santos FDRP, Jesus LMS and Lima RJCP contributed to article writing and final version to be published. Santos LH contributed to the organization, analysis and interpretation of data.

\section{References}

1. Sociedade Brasileira de Diabetes. Diretrizes da Sociedade Brasileira de Diabetes 2013-2014. São Paulo: AC Farmacêutica; 2014.

2. International Diabetes Federation. IDF Diabetes Atlas. Brussels, Belgium: International Diabetes Federation; 2015.

3. Laguna Neto D, Pires AC. Hyperglycemic crises in diabetes mellitus. Current aspects. Rev Bras Clin Med. 2010; 8(3):246-53.

4. Amaral Júnior $\mathrm{AH}$, Amaral LAH, Bastos MG, Nascimento LC, Alves MJM, Andrade MAP. Prevention of lower-limb lesions and reduction of morbidity in diabetic patients. Rev Bras Ortop. 2014; 49(5):482-7. 
5. Caiafa JS, Castro AA, Fidelis C, Santos VP, Silva ES, Sitrângulo Junior CJ. Atenção integral ao portador de pé diabético. J Vasc Bras. 2011; 10(4 supl 2):132.

6. Ferreira V, Martins J, Loureiro L, Loureiro T, Borges L, Silveira D, et al. Multidisciplinary consultation of diabetic foot - factors related with bad prognosis. Angiol Cir Vasc. 2014; 10(3):146-50.

7. Almeida SA, Silveira MM, Espírito Santo PF, Pereira RC, Salomé GM. Assessment of the quality of life of patients with diabetes mellitus and foot ulcers. Rev Bras Cir Plást. 2013; 28(1):142-6.

8. Campolina AG, Bortoluzzo AB, Ferraz MB, Ciconelli RM. Validation of the Brazilian version of the generic six-dimensional short form quality of life questionnaire (SF-6D Brazil). Ciênc Saúde Coletiva. 2011; 16(7):3103-10.

9. Callegari-Jacques SM. Bioestatística. Princípios e aplicações. Porto Alegre: Artmed; 2003.

10. Statistical Analysis System - SAS. SAS software: user's guide. Version 8.2. Cary (NC): SAS Institute Inc., 2000.

11. Rodrigues AN, Szymaniak NP, Andrade Sobrinho $\mathrm{J}$. The role of dermatosis on diabetes patient's quality of life. Ciênc Saúde Coletiva. 2010; 15(supl 1):1325-32.

12. Martin IS, Beraldo AA, Passeri SM, Freitas MCF, Pace AE. Root causes for the development of foot ulcers of people with diabetes mellitus. Acta Paul Enferm. 2012; 25(2):218-24.

13. Dias AFG, Vieira MF, Rezende MP, Oshima A, Muller MEW, Santos MEX et al. Epidemiologic profile and level of knowledge among diabetic patients about diabetes and diabetic retinopathy. Arq Bras Oftalmol. 2010; 73(5):414-8.
14. Salomé GM, Blanes L, Ferreira LM. Functional capability of patients with diabetes with foot ulceration. Acta Paul Enferm. 2009; 22(4):412-6.

15. Salomé GM, Blanes L, Ferreira LM. Assessment of depressive symptoms in people with diabetes mellitus and foot ulcers. Rev Col Bras Cir. 2011; 38(5):327-33.

16. Meneses LC, Blanes L, Veiga DF, Gomes HC, Ferreira LM. Health-related quality of life and self-esteem in patients with diabetic foot ulcers: results of a cross-sectional comparative study. Ostomy Wound Manage. 2011; 57(3):36-43.

17. Coelho MS, Silva DMGV, Padilha MIS. Social representations of diabetic foot for people with type 2 diabetes Mellitus. Rev Esc Enferm USP. 2009; 43(1):65-71.

18. Santos EA, Tavares DMS, Rodrigues LR, Dias FA, Ferreira PCS. Morbilidades y calidad de vida de ancianos con diabetes mellitus residentes en zonas rurales y urbanas. Rev Esc Enferm USP. 2013; 47(2):393-400.

19. Palmeira MM, Silva LL, Sousa RM, Cordeiro CRG. Epidemiological profile of diabetic patients seen at the diagnostic services in cardiology at the University of the State of Pará. Rev Bras Med. 2011; 68(supl 2):29-32.

20. Bona SF, Barbosa MAR, Ferraz CLH, Guarita LKS, Nina RVAH, Brabosa NMRF, et al. Prevalence of diabetic foot in patients treated in the rise of a public hospital tertiary of Fortaleza. Rev Bras Clin Med. 2010; 8(1):1-5. 